\title{
Integration and Management of Technologies Through Practicum Experiences: A Review in Preservice Teacher Education (2010-2020)
}

\author{
Irene García-Lázaro \\ Department of Communication and Education, Faculty of Social and Human Sciences, Universidad Loyola \\ Andalucía, Seville, Spain \\ Department of Research Methods and Diagnosis in Education, Faculty of Education Sciences, University of \\ Seville, Seville, Spain \\ ORCID: 0000-0001-9818-6170 \\ Jesús Conde-Jiménez \\ Department of Educational Theory and History and Social Pedagogy, Faculty of Education Sciences, \\ University of Seville, Seville, Spain \\ ORCID: 0000-0002-4471-5089 \\ María Pilar Colás-Bravo \\ Department of Research Methods and Diagnosis in Education, Faculty of Education Sciences, University of \\ Seville, Seville, Spain \\ ORCID: 0000-0003-3000-075X
}

Received: 11 Nov 2021

Accepted: 29 Dec 2021

\begin{abstract}
The presence and use of technologies in educational settings is constantly increasing. Therefore, initial teacher education needs to prepare future teachers to deal with this technological implementation from both practical and pedagogical perspectives. This paper examines the treatment of technologies that initial teacher education offers to early childhood education and primary education preservice teachers facing their practicum experiences. A bibliometric and thematic review during the 2010-2020 period is conducted in WoS, Scopus, Psyclnfo, and ERIC databases. An analysis of co-occurrence of terms and the creation of bibliometric maps are considered. The thematic analysis follows an inductive approach. Three big areas are addressed through this approximation: consideration of technologies before practicum, the use of technologies at the schools, and the study of preservice teacher's personal variables. Findings show the importance of working with technological preparation of university supervisors and cooperating teachers when teacher candidates do their practicum. In this proposal, to consider the self-efficacy and technological, pedagogical and content knowledge model of preservice teachers is encouraged. Conclusions underline the importance of teaching and strengthening pedagogical and reflective experiences during the practicum. Limitations are considered.
\end{abstract}

Keywords: initial teacher education, bibliometric review, practicum, TPACK, educational technologies, teaching practices

\section{INTRODUCTION}

The presence of technologies in the teacher training continues being an essential topic as they have become subjects into the university curriculum; it is also an axis in teacher competency frameworks such as the European DIGCOMPEDU (Caena \& Redecker, 2019; Reisoglu \& Cebi, 2020). During the initial teacher 
education (ITE), teacher candidates interact with technological tools created to help their professional performance. However, technologies are not only objects; future teachers must develop abilities, attitudes and Technological, Pedagogical and Content Knowledge (TPACK) through their academic training to create successful learning paths for their students (Cabero-Almenara \& Martínez, 2019; Mishra \& Koehler, 2006; Starkey, 2020). We need to consider children' interactions with technology in their daily routine to teach preservice teachers (PTs) pedagogical uses of technologies. Regarding practicum experiences, the increase of technologies in early childhood and primary education classrooms allows PTs to manage devices and tools while helping children to reach learning outcomes (Area-Moreira et al., 2016).

Technologies are transversal components for the ITE (United Nations Educational, Scientific and Cultural Organization, 2016), thus, the responsibility toward learning about technologies' management in practicum settings starts from university supervisors (USs) and cooperating teachers (CTs). They become pivotal agents to confront a possible blended learning and to guide and encourage teacher candidates to use technologies in their teaching (Sola-Martínez et al., 2020). Recently, COVID-19 has forced the ITE to transform the way PTs learn, for instance, supervising and planning the teaching strategies to fulfil new challenges that face-to-face education confronts. Although practicum is part of this transformation due to the strong on-site character that it presents, teaching practices prepare PTs for their future profession so more technological experiences start to be considered to continue showing the characteristics that a school involves from an online perspective (i.e., simulation of practicum experiences) (Kim, 2020; Sasaki et al., 2020). However, there is a lack of information about how PTs, CTs and USs interact in practicum contexts considering the management of technologies. For instance, recent literature points to the relationship between internal variables of PTs and the TPACK model in the improvement of their practicum experiences as well as in personal perceptions toward their professional roles (Han et al., 2017; McGarr \& Gallchóir, 2020; Polly et al., 2010).

Thus, further research of this issue is needed to clarify two areas of interest from bibliometric and thematic points of view: the tendency of publication about this topic, and the consideration of variables related to technologies before and during practicum.

\section{PURPOSE}

The purpose of this study is to draw a visual and comprehensible examination of the perceptions and treatment of technologies made through ITE toward practicum experiences. This aim involves the training offered by USs, as well as the subsequent work from schools made by CTs. This general objective is explained through specific research questions related to each area of study:

1. First area: Bibliometric information.

What countries and journals have the most articles published? What methodological designs are the most predominant in this area?

2. Second area: Thematic analysis.

a. Before the practicum: Are technologies part of the previous training to the practicum? Are technologies presented as resources or as reflection mechanisms?

b. During the practicum: How are technologies used at the schools? What is the role of CTs? What variables are involved in PTs' management of technologies?

\section{METHODOLOGY}

\section{Identification and Selection of Articles}

To conduct the review, this study replicates the methodological guidelines provided by Fernández-Batanero et al. (2019) and Starkey (2020). Thus, the focus of this contribution is the search of three cornerstones: a) technologies, b) practicum, and c) preservice teachers. The methodology pattern starts with the identification of the articles sample that follows these three cornerstones. The comparison of different 
databases method was selected as the most suitable tool to measure trends in educational research (LevineClark \& Gil, 2009).

Thus, a quantified bibliographical search related to technologies in practicum settings was conducted in four educational data bases: ERIC, PsycInfo, Scopus, and Web of Science (WoS). It is a computer-assisted search developed from January 2020 to September 2020. A deductive approach is selected to do the exploration: some keywords from the research questions were selected to guide the first exploration, later, some replacement terms were selected, and finally, a search string was proposed through the combination of Boolean operators with keywords. The search within keywords allows to find the most relevant articles suggesting specific descriptors that would appear on the title, keywords and abstract. The descriptors were: ((ICT) OR (TIC)* OR (Technolog*) AND ((Practicum*) OR (Teaching Practice) OR (Student Teaching) OR (Field Experience)) AND ((preservice teacher) * OR (pre-service teacher) OR (student teacher*) OR (teacher candidate)).

The first filtering is conducted through previous mentioned descriptors. If there were enough information in the summary to consider the article, it was exported to the information management platform (Mendeley). However, if any aspects were not clear after reading the summary of the articles (i.e., sample, PTs's bachelor's degree, collection data process, etc.), it was decided to download and read the complete contribution to check the adequacy of a second reading. When the first filtering was successful, the article was imported to Mendeley. Mendeley allowed to classify papers in different folders for each data base; it also showed bibliometric details, such as the country and continent of origin, the date of publication, etc. It also allowed to create a workgroup where authors discussed together about readings and the final decisionmaking. It enabled highlighting and creating memos (notes) for a deep analysis of the information.

\section{Inclusion and Exclusion Criteria}

Table 1 and Table 2 show the followed criteria to include or exclude any studies.

Table 1. Selection criteria

\begin{tabular}{lcccccc}
\hline Articles & Area & Period & Review & PTs courses & Language \\
\hline Empirical Review & $\begin{array}{c}\text { Social sciences \& } \\
\text { education }\end{array}$ & $2010-2020$ & $\begin{array}{c}\text { Peer- } \\
\text { review }\end{array}$ & $\begin{array}{c}\text { Early } \\
\text { childhood }\end{array}$ & $\begin{array}{c}\text { Primary } \\
\text { education }\end{array}$ & Spanish English \\
\hline
\end{tabular}

Table 2. Exclusion criterio

\begin{tabular}{|c|c|c|c|c|}
\hline \multicolumn{3}{|c|}{ Area of interest } & \multicolumn{2}{|l|}{ Type of manuscript } \\
\hline $\begin{array}{l}\text { Subjects or programs } \\
\text { (methods course) }\end{array}$ & $\begin{array}{l}\text { Evaluations (e- } \\
\text { portfolios) }\end{array}$ & $\begin{array}{l}\text { Specific topics (Special } \\
\text { Education Needs, EFL...) }\end{array}$ & $\begin{array}{l}\text { Incomplete Dissertation Book } \\
\text { text }\end{array}$ & $\begin{array}{l}\text { Conference } \\
\text { Proceedings }\end{array}$ \\
\hline
\end{tabular}

\section{FINDINGS}

The first filtering resulted in a sample of 172 articles. A complete reading excluded 135 articles. Finally, 37 articles were considered. Within the total number of studies, 12 studies were found in the four databases; thus, exclusively, 31 articles were selected from ERIC, 16 articles from Psyclnfo, 33 articles from Scopus, and 27 from WoS. 35 articles were traditional empirical studies and 2 manuscripts were empirical research based on ongoing projects $(4 ; 25)$. Table 3 summarises the identification data of the articles; authorship is numbered to facilitate the future reading in advance.

The analysis in Mendeley was guided by the three main cornerstones and notes were taken in relation to the framed research questions. The latent topics were identified through collecting as much information as possible to make the thematic analysis. This examination identified the axis patterns used for the construction of each article. Constant readings were needed to understand these patterns and different ones that emerged. 
Table 3. First author, journal, and database (DB) indexing information

\begin{tabular}{|c|c|c|c|c|c|c|c|}
\hline First author & Country & Journal & ERIC & Psyclnfo & Scopus & WoS & All DBs \\
\hline 1. Aslan and Zhu (2015) & Turkey & $\begin{array}{l}\text { TOJET: The Turkish Online Journal of } \\
\text { Educational Technology }\end{array}$ & $\mathrm{X}$ & $\mathrm{X}$ & $\mathrm{X}$ & & \\
\hline 2. Aslan and Zhu (2016) & Turkey & $\begin{array}{l}\text { International Journal of Research in Education } \\
\text { and Science }\end{array}$ & $\mathrm{x}$ & & $\mathrm{x}$ & & \\
\hline 3. Aslan and Zhu (2017) & UK & British Journal of Educational Technology & & & & & $x$ \\
\hline $\begin{array}{l}\text { 4. Bladergroen and Chigona } \\
\text { (2019) }\end{array}$ & $\begin{array}{l}\text { South } \\
\text { Africa }\end{array}$ & Africa Education Review & $\mathrm{x}$ & & $\mathrm{x}$ & $\mathrm{x}$ & \\
\hline 5. Browne (2015) & Australia & $\begin{array}{l}\text { Asia-Pacific Journal of Health, Sport and } \\
\text { Physical Education }\end{array}$ & $x$ & & $x$ & & \\
\hline 6. Cakir and Yildirim (2013) & Philippines & The Asia-Pacific Educational Research & $x$ & & & $x$ & \\
\hline 7. Charbonneau-Gowdy (2015) & UK & The Electronic Journal of e-Learning & $\mathrm{x}$ & & $\mathrm{x}$ & $\mathrm{x}$ & \\
\hline 8. Chen (2010) & UK & Computers \& Education & & & & & $x$ \\
\hline 9. Dong and Mertala (2019) & UK & Early Years. An International Research Journal & & & $\mathrm{x}$ & & \\
\hline 10. Figg and Jamani (2011) & Australia & Australasian Journal of Educational Technology & $x$ & & $x$ & $\mathrm{x}$ & \\
\hline 11. Franklin et al. (2018) & USA & TechTrends & $\mathrm{x}$ & & & $\mathrm{x}$ & \\
\hline 12. Gao et al. (2011) & Australia & Australasian Journal of Educational Technology & $\mathrm{x}$ & & $x$ & $\mathrm{x}$ & \\
\hline 13. Gill et al. (2014) & Australia & Australian Journal of Teacher Education & $\mathrm{x}$ & & $\mathrm{x}$ & $x$ & \\
\hline 14. Gill and Dalgarno (2017) & UK & Technology, Pedagogy and Education & & & & & $\mathrm{x}$ \\
\hline 15. Goldstein and Tesler (2017) & USA & $\begin{array}{c}\text { Interdisciplinary Journal of E-skills and Lifelong } \\
\text { Learning }\end{array}$ & $\mathrm{x}$ & & & & \\
\hline 16. Guillén-Gámez et al. (2018) & Australia & Technology, Knowledge and Learning & & $\mathrm{x}$ & $x$ & $\mathrm{x}$ & \\
\hline 17. Habibi (2020) & USA & The qualitative Report & & & $\mathrm{x}$ & & \\
\hline 18. Hammond et al. (2011) & UK & Journal of Computer Assisted Learning & & & & & $x$ \\
\hline 19. Hu and Yelland (2017) & USA & Journal of Early Childhood Teacher Education & & & & & $\mathrm{x}$ \\
\hline $\begin{array}{l}\text { 20. Instefjord and Munthe } \\
\text { (2017) }\end{array}$ & UK & Teaching and Teacher Education & & $\mathrm{x}$ & $\mathrm{x}$ & $\mathrm{x}$ & \\
\hline 21. Jita (2016) & $\begin{array}{l}\text { South } \\
\text { Africa }\end{array}$ & Perspectives in Education & $\mathrm{x}$ & & $\mathrm{x}$ & & \\
\hline 22. $\operatorname{Kim}(2020)$ & Australia & International Journal of Early Childhood & & $x$ & $x$ & $x$ & \\
\hline 23. Maestre et al. (2017) & Spain & $\begin{array}{l}\text { Bordón. Revista de Pedagogía } \\
\text { [Staff. Pedagogy Magazine] }\end{array}$ & & & $\mathrm{x}$ & $x$ & \\
\hline 24. Martinovic and Zhang (2012) & UK & Teaching and Teacher Education & & & & & $\mathrm{x}$ \\
\hline 25. Melville et al. (2011) & Spain & $\begin{array}{c}\text { Electronic Journal of Research in Educational } \\
\text { Psychology }\end{array}$ & & & & & $x$ \\
\hline 26. Merc (2015) & Turkey & $\begin{array}{l}\text { TOJET: The Turkish Online Journal of } \\
\text { Educational Technology }\end{array}$ & $\mathrm{x}$ & $\mathrm{x}$ & $\mathrm{x}$ & & \\
\hline 27. Mouza et al. (2014) & UK & Computers \& Education & & $\mathrm{x}$ & $\mathrm{x}$ & $\mathrm{x}$ & \\
\hline 28. Ntuli (2017) & USA & Open Journal for Educational Research & $x$ & & & $x$ & \\
\hline 29. Olivares and Castillo (2018) & USA & Education and Information Technologies & $\mathrm{x}$ & & $x$ & $\mathrm{x}$ & \\
\hline 30. Rowston et al. (2019) & USA & Education and Information Technologies & $x$ & & $x$ & $x$ & \\
\hline 31. Sahin and Kabakci (2014) & Turkey & Education Sciences: Theory and Practice & & & & & $x$ \\
\hline 32. Szeto and Cheng (2014) & Philippines & The Asia-Pacific Educational Research & $x$ & & $x$ & $x$ & \\
\hline 33. Szeto and Cheng (2016) & USA & Journal of Educational Computing & & & & & $x$ \\
\hline 34. Vratulis et al. (2011) & UK & Teaching and Teacher Education & & & & & $x$ \\
\hline 35. Wake (2013) & USA & $\begin{array}{c}\text { Contemporary Issues in Technology and } \\
\text { Teacher Education }\end{array}$ & $x$ & & $x$ & & \\
\hline 36. Walker et al. (2019) & USA & The New Educator & $x$ & & $x$ & $x$ & \\
\hline 37. Zipke (2017) & Philippines & The Asia Pacific Journal Of Education & $x$ & & $X$ & & \\
\hline \multicolumn{3}{|c|}{ Total } & 31 & 17 & 33 & 27 & 10 \\
\hline
\end{tabular}

\section{First Part: Bibliometric Information}

The number of publications related to use of technologies, field experiences and preservice teachers from early childhood or primary education is limited. In Table 3, information related to the journal's country of origin as well as the countries where research is most developed can be seen. The highest publication rate is found in 2011 and 2017, with 5 and 8 publications, respectively. The years 2014, 2015, and 2019 also present some publications (4 respectively). Six journals published more than one article from 2011 to 2020: Australasian Journal of Educational Technology $(10 ; 12)$, Teaching and Teacher Education $(20 ; 24 ; 34)$, Computers \& Education (8; 27), Education and Information Technologies (29; 30), The Asia-Pacific 


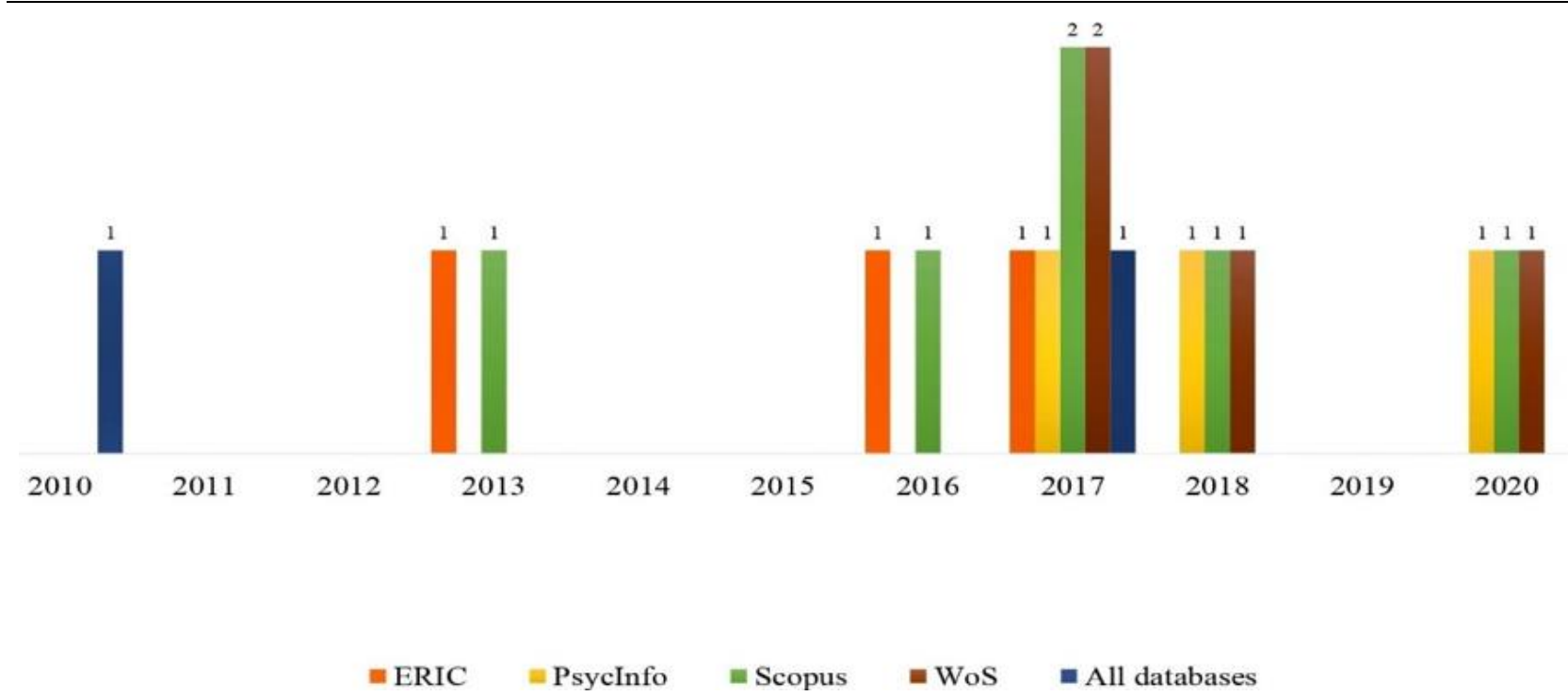

Figure 1. Quantitative approach by database and year of publication

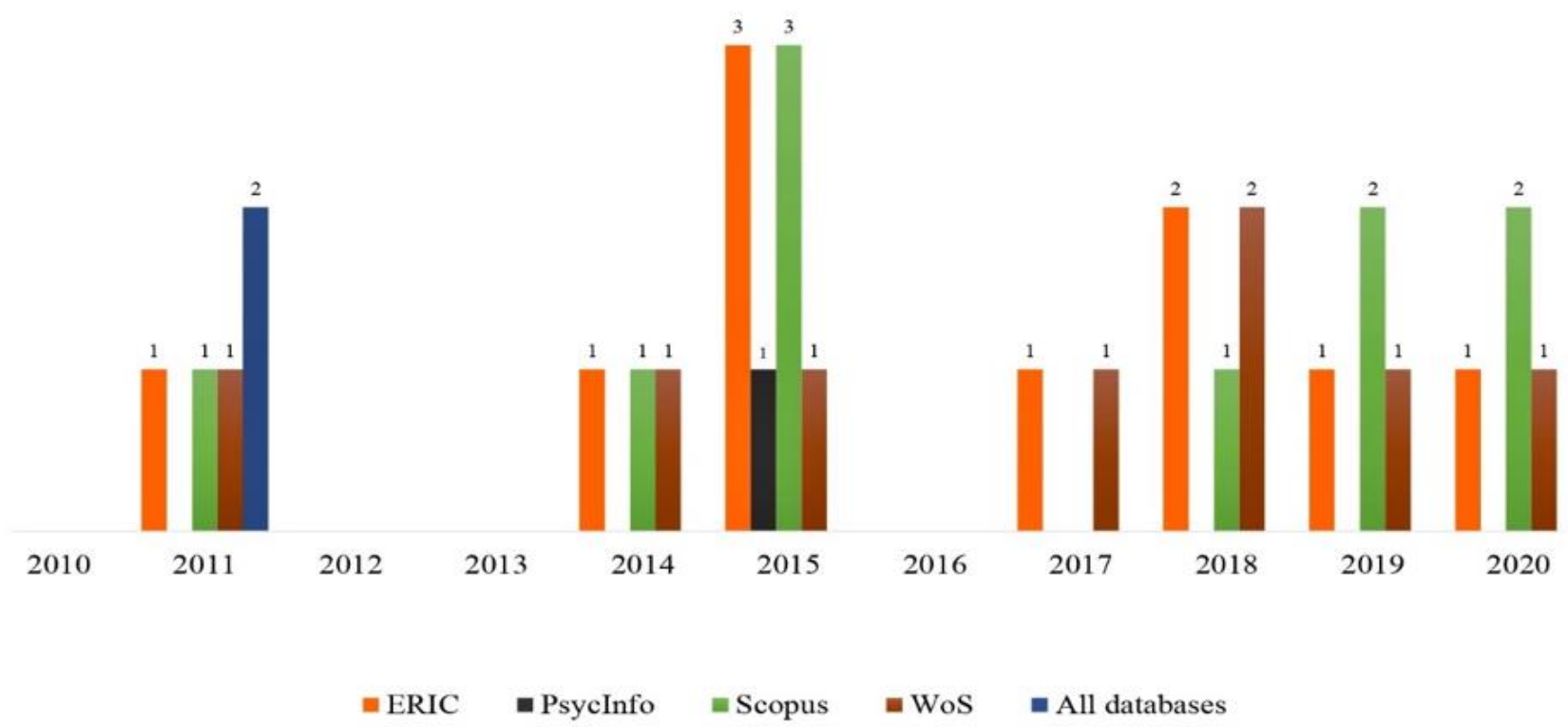

Figure 2. Qualitative approach by database and year of publication

Educational Research (6; 32), TOJET: The Turkish Online Journal of Educational Technology (1; 26), and Education and Information Technologies (29; 30).

The main research design is clearly qualitative in the last decade. The predominant methodological design is the case study through interviews, observations and field notes, analysis of documents (narratives, diaries, portfolios, etc.) and focus groups (see Figure 1, Figure 2, and Figure 3). Secondly, the mixed methodology combines surveys and questionnaires or scales with interviews and focus groups. Thirdly, exploratory studies, with non-experimental, cuasi-experimental, correlational designs and the design and validation of structural equation models were found (respectively). Scales, surveys, and questionnaires are the most used quantitative techniques. As Figure 1, Figure 2, and Figure $\mathbf{3}$ show, some of the articles appeared in more than one database, or in all databases. Scopus presents the highest rate of publication in relation to quantitative studies. In relation to qualitative research, ERIC and Scopus present the same rate of publications. ERIC is the database that publishes more mixed papers.

The quantitative approach presents most of publications in 2017, the qualitative approach obtained the highest rate in 2015, and the mixed methodology presents the highest level of publications in 2014. As the figures show, databases with a greater influence internationally (WoS and Scopus) presented less articles about this issue. 


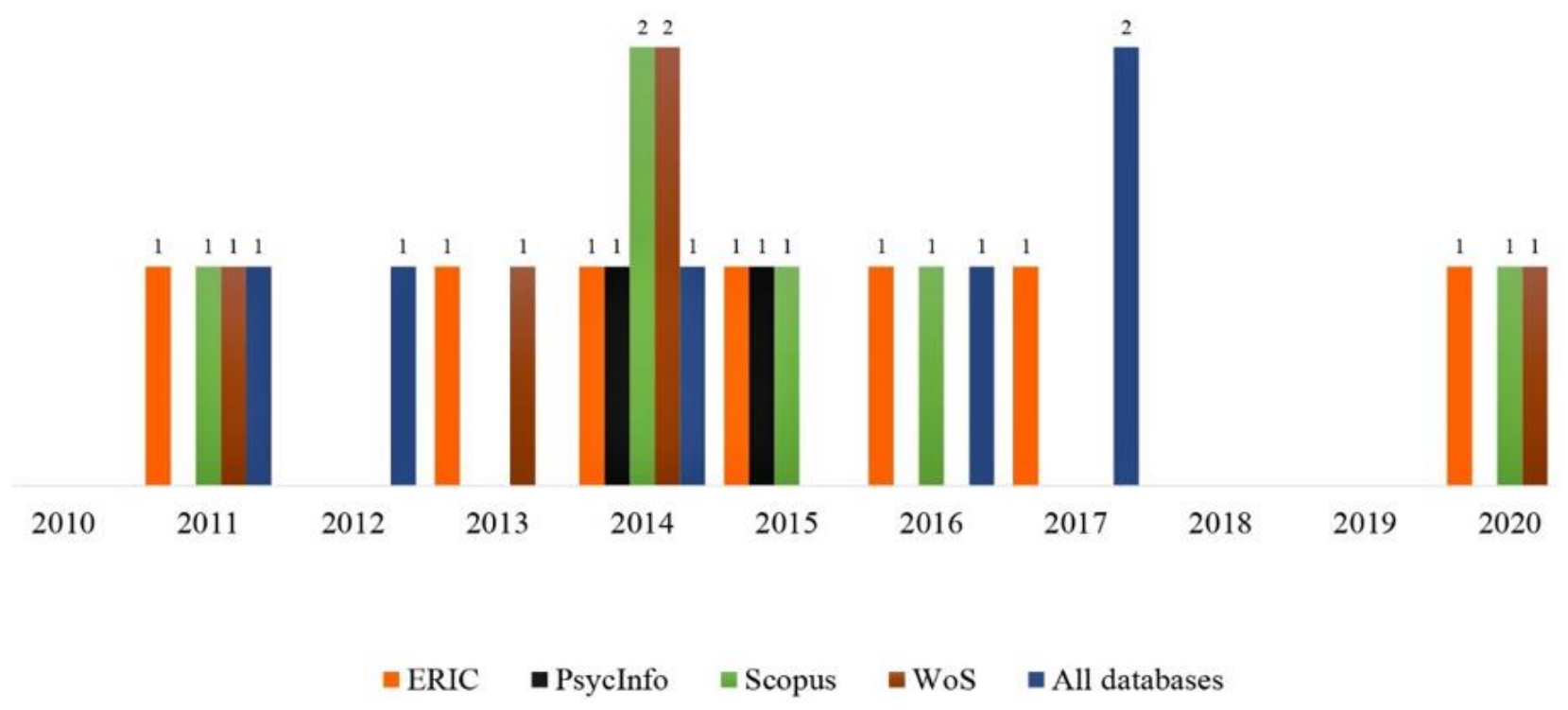

Figure 3. Mixed methodological approach by database and year of publication

According to the inclusion criteria, the number of articles is reduced from 2010 to 2020. Methodologically, some contributions created structural equation models to explain the relationships between specific variables that intervene in the topic of this issue $(3 ; 8)$. Quantitative articles presented exploratory analysis, correlations, and regressions to show descriptive data $(2 ; 6 ; 16 ; 12 ; 18 ; 19 ; 20 ; 21 ; 24 ; 26 ; 27 ; 31 ; 32 ; 36 ; 37)$. Qualitative findings present specific cases that are illustrative for future replications in similar contexts $(1 ; 4$; $5 ; 6 ; 7 ; 9 ; 10 ; 11 ; 12 ; 13 ; 14 ; 17 ; 18 ; 19 ; 21 ; 22 ; 24 ; 25 ; 26 ; 27 ; 28 ; 29 ; 30 ; 31 ; 32 ; 33 ; 34 ; 36 ; 37)$.

VOSViewer software was used to build a visual interpretation of the co-occurrence of the cornerstones for the research. This analysis presents to what extent a term and a group of related terms appear in the search about the topics of our review. KW+ system was selected to obtain bibliometric results from WoS and Scopus databases since both are the most visited platforms internationally (Pranckutè, 2021). The search filters in WoS were $K W+$, co-occurrence and full counting; the filters in Scopus were co-occurrence and all keywords.

\section{Bibliometric analysis from Web of Science (WoS)}

The homogeneity of the search's results in WoS was analysed and three thematic clusters were found through VOSViewer (see term map in Figure 4 and density map in Figure 5). The weight of each descriptor (term) corresponds to the size of the node. The node also represents the term's links with other descriptors. These links (curves lines) describe the connections shared by the nodes. The proximity between two descriptors also represents the strength of the relationship. In Figure 4, the size represents the frequency of appearance of the descriptor; the intensity of the clusters come from the number of $\mathrm{KW}+$, the frequency of occurrence of those $\mathrm{KW}+$, etc. The red cluster (the most highlighted and the biggest one) implies a high correlation of $\mathrm{KW}+$; however, clusters that appear in the margins of the image show a low correlation. The three clusters (red, green, and blue, in order of relevance) show our three cornerstones:

- Red Cluster 1: It represents the findings related to the PTs' training, that is, the role played by PTs and their USs. We find terms such as teacher educator, reflection, opportunity, teacher education program, knowledge, etc. This cluster involves 34 terms. Since the size of the descriptors determines the weight of the cluster, the terms with the highest weight are preservice teacher (links=59, occurrences $=128$, total link strength=697), knowledge (links=57, occurrences=96, total link strength=541), teacher education program (links=46, occurrences=30, total link strength=324) teacher educator (links=53, occurrences=39, total link strength=214). 


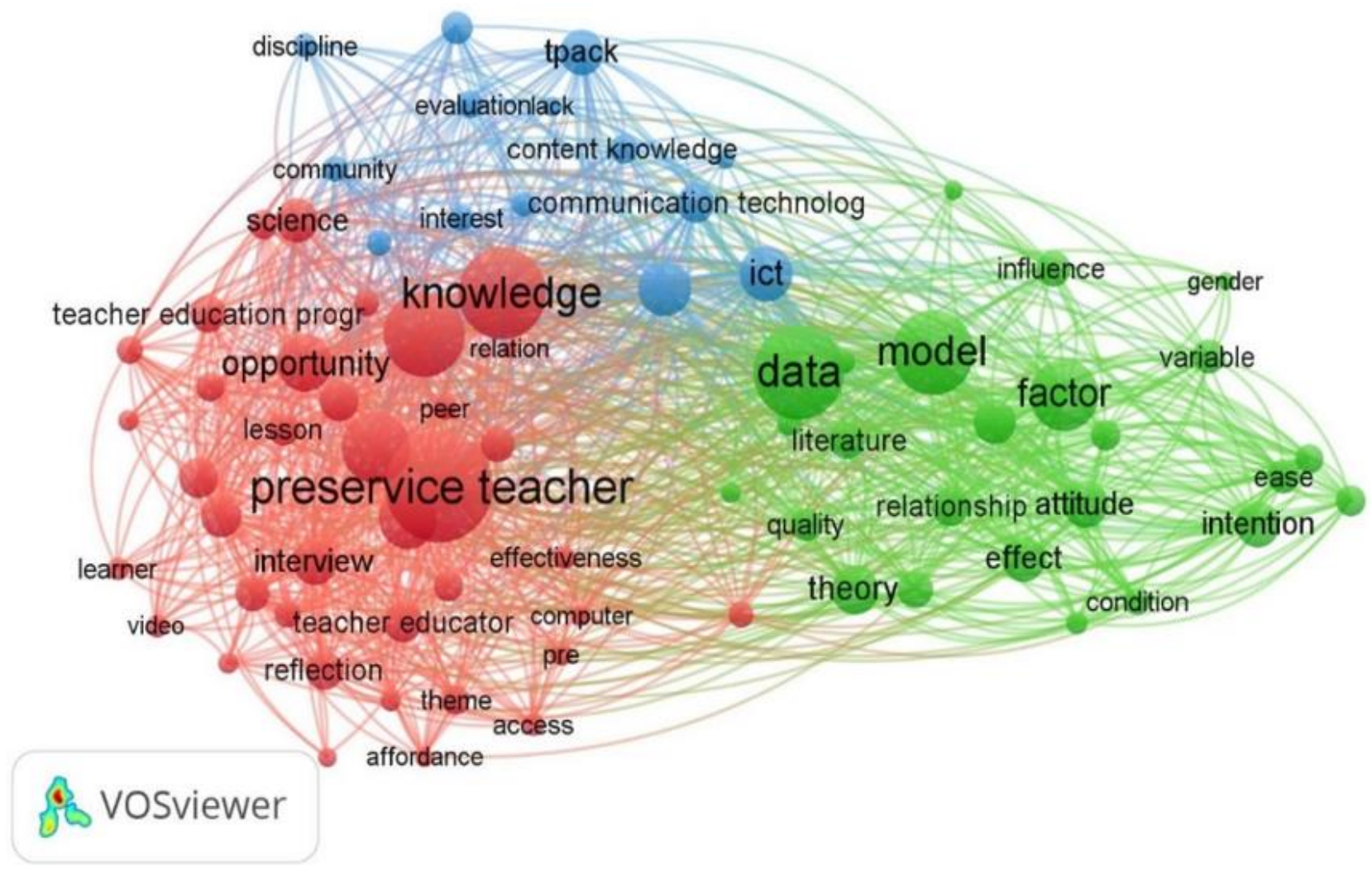

Figure 4. Term map for WoS analysis

- Green Cluster 2: It represents variables in practicum settings and their relationship with the use of technology. This cluster involves 19 terms. The heaviest descriptors are mode (links=58, occurrences $=79$, total link strength $=528$ ), data (links=59, occurrences $=54$, total link strength=483), factor (links $=58$, occurrence $=59$, total link strength $=424$ ), influence (links $=47$, occurrence $=184$, total link strength=27), attitude (links=50, occurrence $=336$, total link strength=38), and theory (links=56, occurrence $=264$, total link strength $=37$ ).

- Blue Cluster 3: It involves everything related to technologies. This cluster includes 7 descriptors. The most highlighted terms are: TPACK (links=48, occurrences $=295$, total link strength=38), technological pedagogical content knowledge (links $=43$, occurrences $=275$, total link strength $=65$ ), content knowledge (links $=45$, occurrence $=245$, total link strength $=27$ ), ICT (links $=56$, occurrences $=331$, total link strength=48), and communication technology (links $=54$, occurrence $=221$, total link strength=28).

In the density map (Figure 5), the KW+ circles and the colour indicate the relevance level of each descriptor. The $\mathrm{KW}+$ related to the field of practicum and ITE is coloured in yellow and is located in the centre of the image, that is, a high relevance of its co-occurrence (preservice teacher, teacher education program, teacher educator, TPACK, data, model, factor, attitude). The colour green-blue represents less density of cooccurrences of $\mathrm{KW}+$ (gender, discipline, access, effectiveness). 


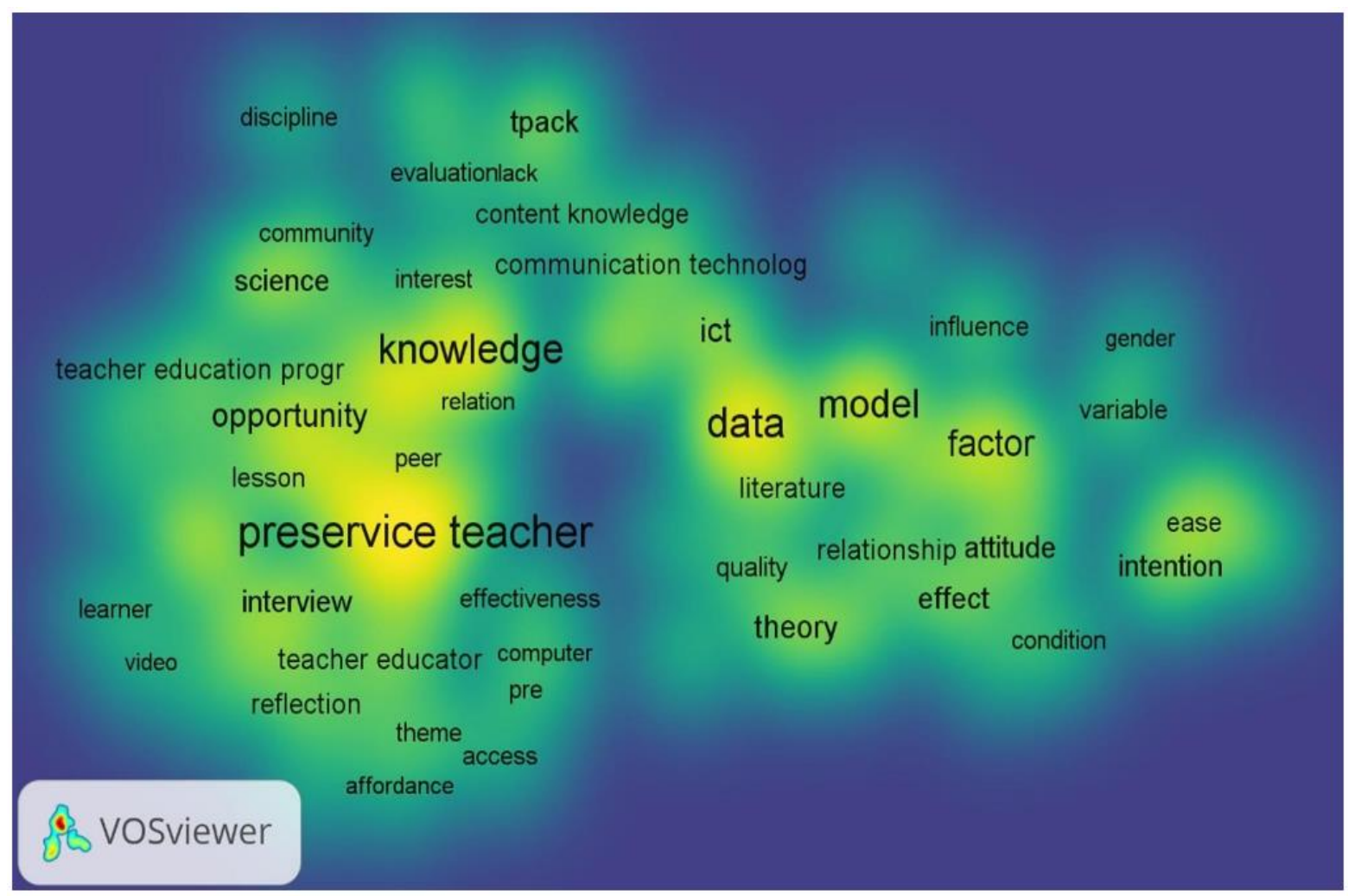

Figure 5. Density map for WoS analysis

\section{Bibliometric analysis from Scopus}

The search of information's homogeneity was analysed. Four thematic clusters were obtained: red, blue, green, and yellow (Figure 6):

- Red Cluster 1: It represents the bases of the ITE. It includes terms such as educator, reflection, instruction, lesson, pedagogy, etc. This cluster involves 12 terms. The heaviest terms are educator (links $=35$, occurrences $=200$ and total link strength $=52$ ), reflection (links $=35$, occurrences $=117$, total link strength=31), instruction (links=35, occurrences $=120$, total link strength=31) and pedagogy (links=33, occurrences $=103$, total link strength=27).

- Green Cluster 2: It represents factors that intervene in the ITE through using technologies. It includes terms such as ability, effect, environment, etc. This cluster involves 11 descriptors. The heaviest items are teaching practice (links $=34$, occurrence $=102$, total link strength=28), university (links=33, occurrences $=109$, total link strength $=35$ ) environment (links $=35$, occurrences $=113$, total link strength=30), information (links=34, occurrences=108, total link strength=25), and attitude (links=29, occurrences $=66$, total link strength $=20$ ).

- Blue Cluster 3: It involves factors that mediate the training and learning process through field experiences. This cluster includes 8 descriptors. There are terms such as interest, implementation, professional development, etc. The most highlighted items are interview (33 links, 114 occurrences and 32 total link strength), training (links $=28$, occurrences $=81$, total link strength $=26$ ), integration (links $=31$, occurrence $=104$, total link strength $=26$ ) and implementation (links $=31$, occurrences $=72$, total link strength=20).

- Yellow Cluster 4: This cluster represents technologies shown and used through ITE by PTs. This cluster involves 5 items. The heaviest terms are TPACK (links=35, occurrences=99, total link strength=32), content knowledge (links $=26$, occurrences $=6$, total link strength $=16$ ), and technological pedagogical content knowledge (links=33, occurrences $=90$, total link strength $=18$ ). 


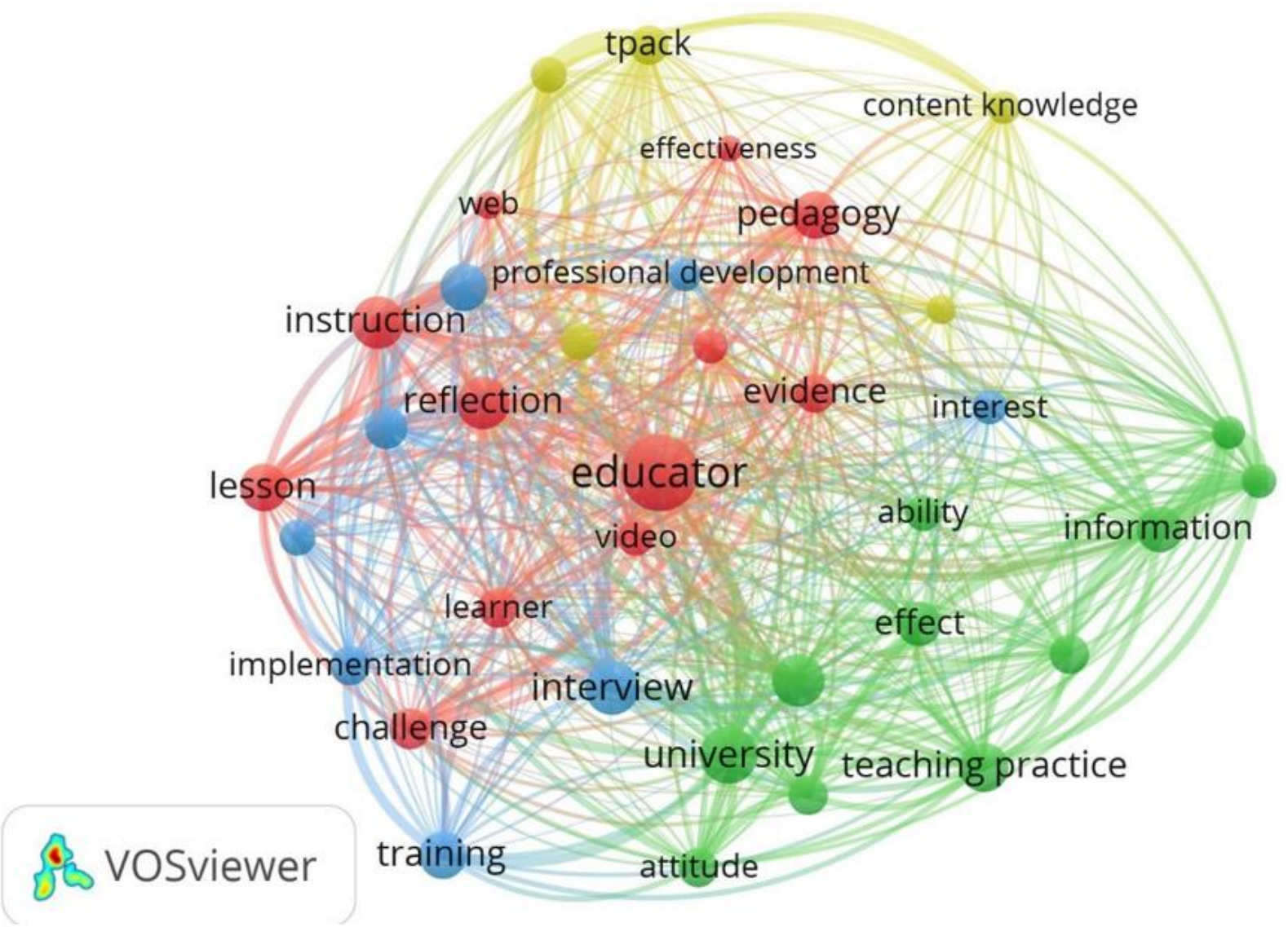

Figure 6. Term map for Scopus analysis

In the density map (Figure 7), the KW+ circles and their colour indicate the level of relevance of the terms. The $\mathrm{KW}+$ that relates the practicum and ITE is place in the centre, in intense yellow. It represents high relevance of its co-occurrence (educator, university, teaching practice, instruction, reflection). The colour green-blue represents less density of co-occurrences of $\mathrm{KW}+$ (evidence, interest, ability).

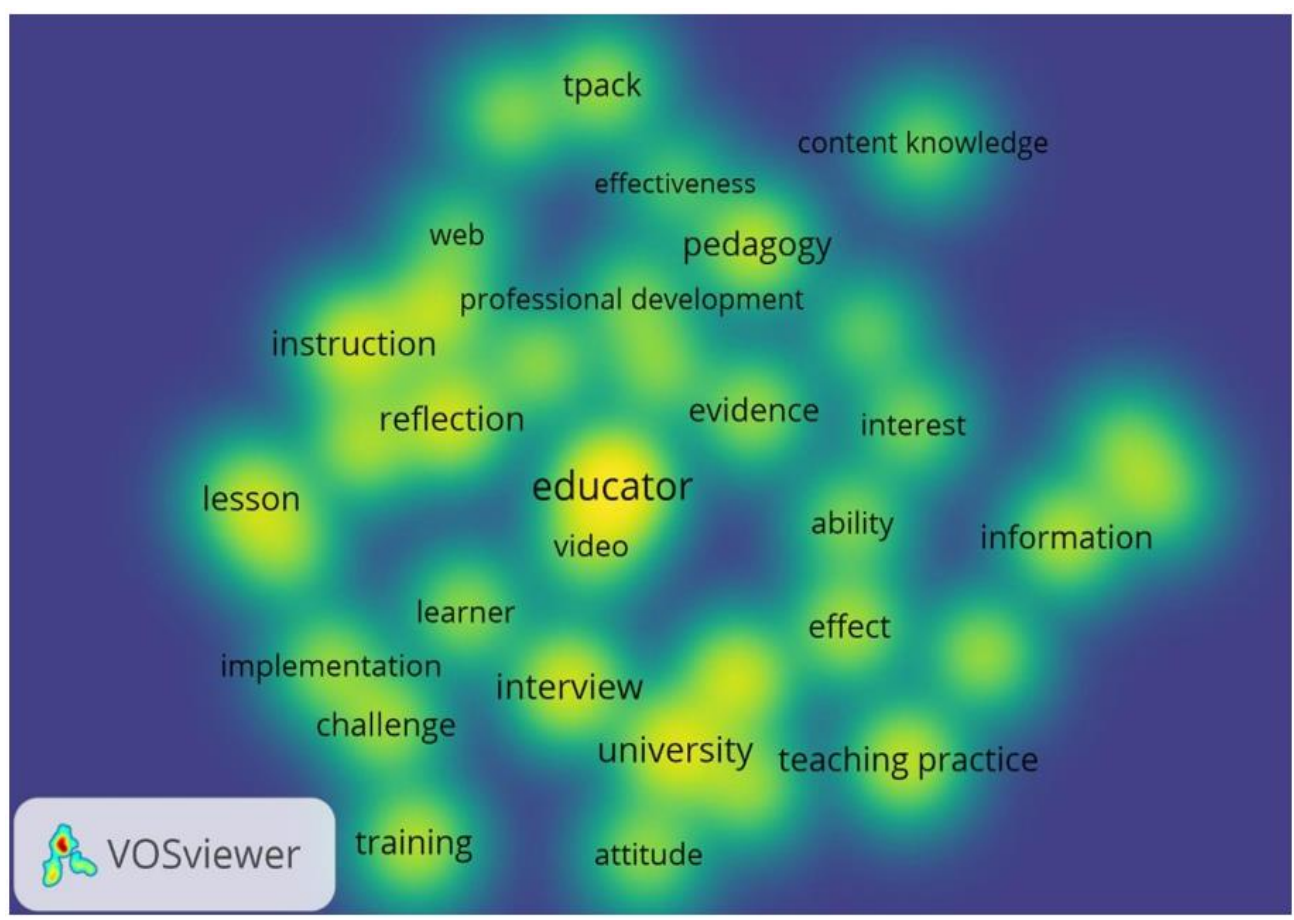

Figure 7. Density map for Scopus analysis 


\section{Second Part: Thematic Analysis}

Three research lines are developed into the literature as Table 4 presents: the presence of the review's topic in the ITE and the role of USs, the presence of the topic at the schools and the mediation of CTs, and the study of internal variables of PTs. Findings are presented following the research questions for the thematic analysis. In Table 4, all articles are categorised regarding the research lines they present.

Table 4. Identified topics within the review

\begin{tabular}{|c|c|c|c|}
\hline Article & University training-US's support & Field experiences-CT's support & PTs internal variables \\
\hline 1 & $x$ & $x$ & $x$ \\
\hline 2 & & $X$ & $X$ \\
\hline 3 & & $X$ & $X$ \\
\hline 4 & $x$ & $x$ & \\
\hline 5 & & $x$ & \\
\hline 6 & & $\mathrm{x}$ & $\mathrm{x}$ \\
\hline 7 & $X$ & $X$ & $X$ \\
\hline 8 & & $x$ & $x$ \\
\hline 9 & & $x$ & \\
\hline 10 & & $X$ & $X$ \\
\hline 11 & $X$ & $X$ & \\
\hline 12 & $x$ & $x$ & $x$ \\
\hline 13 & & $x$ & $x$ \\
\hline 14 & $x$ & $x$ & $x$ \\
\hline 15 & $x$ & $x$ & $x$ \\
\hline 16 & & $x$ & $x$ \\
\hline 17 & $x$ & $x$ & $x$ \\
\hline 18 & & $x$ & $x$ \\
\hline 19 & & $X$ & \\
\hline 20 & & $X$ & $X$ \\
\hline 21 & & $x$ & $x$ \\
\hline 22 & $x$ & $x$ & \\
\hline 23 & & $x$ & $x$ \\
\hline 24 & $X$ & $X$ & $X$ \\
\hline 25 & & $X$ & $X$ \\
\hline 26 & & $x$ & $x$ \\
\hline 27 & $x$ & $x$ & $x$ \\
\hline 28 & & $x$ & \\
\hline 29 & $x$ & $X$ & $X$ \\
\hline 30 & & $x$ & $x$ \\
\hline 31 & & $x$ & \\
\hline 32 & $x$ & $x$ & \\
\hline 33 & & $x$ & $\mathrm{x}$ \\
\hline 34 & & $x$ & \\
\hline 35 & & $x$ & \\
\hline 36 & $x$ & $x$ & $x$ \\
\hline 37 & $X$ & $X$ & $x$ \\
\hline
\end{tabular}

\section{Consideration of Technologies Before the Practicum}

In this review, the technological "preparation" of PTs presents different research paths. In fact, article 3 highlighted university training as a predictor of technologies implementation in PTs' teaching practices. Moreover, some articles $(10 ; 15 ; 37)$ highlighted that previous university training favoured the learning that happens through integrating technologies during the practicum because it made PTs feel comfortable addressing this use.

On the one hand, the ITE preparation was based on methods courses, specific subjects related to the management of technological tools, and preparation courses facing the practicum. These experiences were focused on teaching PTs how to use applications, software, and programmes. For instance, article 27 pointed 
out the relevance of methods course in discovering useful resources for the subsequent teaching practice. Some articles $(7 ; 11)$ also highlight tools, such as Web-Base activities, Skype, blogs, and robotics shown during specific sessions at the university. In the line of managing and improving technological skills, article 15 presents the contribution of learning management systems (LMS), synchronous meeting environments and social networks.

The research also addressed the role of USs through these training courses. Articles 17 and 20 found a lack of training of USs that determined their transformation on good technological educational leaders. This fact also could influence the development of digital competence put into practice in schools' settings. In contrast, article 18 already found that teacher candidates appreciated positive support from their USs. Their responsibility went beyond the teaching task; USs also needed to guide preservice teachers in ethical issues, for instance, in the use of specific technological tools (32). Through all these findings, the scaffolding idea appears as follows: firstly, scaffolding happens thanks to the ITE beyond the feedback and encouragement of USs, and secondly, it happens when USs and other agents helped PTS to be autonomous in their practices.

On the other hand, disadvantages from the PTs' perspectives toward these initiatives are presented. Article 1 found that the preparation course was insufficient as it only proposed to create resources instead of developing pedagogical strategies. PTs thought that resources are easily found in school settings most of the times, however, how to use them became the key task. In the same line, articles 4 and 12 pointed out the strengthening of the university training for later successful field experiences. For instance, article 29 explored the use of interactive whiteboards through practicum. Teacher candidates perceived a lack of strategies and methodological guidance to use later the tool effectively and they would have liked previous stronger training. Article 36 recently found similar results: PTs perceived insecurity and discomfort facing mobilelearning integration at the schools. In this line, some of the studies $(11 ; 12 ; 25)$ concluded that university faculty tried to promote reflection processes through this technological training. They framed this purpose within LaBoskey, Schön, and Vygotsky' frameworks about reflective processes. However, findings present low levels of reflection at the schools in contrast with high rate of use of basic tools.

\section{Use of Technologies in Practicum Settings}

With respect to the treatment of technologies at the schools, the review presents conclusions related to the quality and quantity of technological tools at the schools, the support and role of CTs, and the relationship between internal variables of PTs and the context of practicum.

Firstly, technological resources are limited into the classroom and school contexts from the PTs's point of view. They report that computers and laptops (9), projectors $(16 ; 26)$, tablets $(5)$, and interactive whiteboards $(9 ; 29)$ were the main tools. The most used programs were Power Point, Web-quest, WebCt, and Youtube ( 3 ; $12 ; 25 ; 35)$. Only article 24 found a higher availability of resources at the school compared to the university. Some authors talked about the difficult access to use these resources. In cases where technology is present the use is limited and it is made in a traditional way, keeping the focus on facilitating the teacher's job instead of the children' learning: teacher-centre approach $(2 ; 7 ; 12 ; 15 ; 26 ; 33)$. In fact, article 19 point out that a teacher-directed pedagogical approach blocked the development of autonomous technological skill and attitude in the pupils. These authors also found that curriculum is one of the most determinant variables when implementing technology. Secondly, some studies $(22 ; 24 ; 34)$ pointed out other external barriers that blocked the appropriate development of digital competence, such as the school vision, families, and the curriculum.

The support and guidance of CTs is a highlighted issue. In general, PTs reported high expectations toward their CTs' functions, however, findings showed little support from CTs to integrate technologies in PTs's teaching. CTs used basic programs in a traditional way, thus, it made the experience less interesting $(7 ; 13$; $15 ; 16)$. Moreover, the training that CTs showed was poor and reduced to answer technological demands from the PTs's point of view $(13 ; 15 ; 19 ; 1 ; 32 ; 37)$. In terms of monitoring, article 37 reported that PTs wanted to find better feedback when they intervened in the lessons. Thus, this scaffolding by CTs at the schools became an issue in the implementation of innovative technological practices. Although article 17 presented that CTs provided security and self-confidence to develop a stronger technological content knowledge and 
pedagogical knowledge, many other articles found their support was insufficient $(4 ; 5 ; 7 ; 13 ; 15 ; 19 ; 28 ; 29$; $31 ; 32 ; 34 ; 35 ; 37)$.

Regarding the perceived support, article 4 explained that PTs would have liked to find more advice in their technological interventions; they expected to learn more about technologies advancements in the schools. Although PTs considered necessary to reflect about technologies' role in the teaching-learning process, the inability of CTs avoided reflecting. Specifically, PTs talk about the lack of support and encouragement from their CTs to promote the use of technologies: article 5 explored the perceptions toward the use of tablets and PTs did not feel secure and comfortable although they thought they were prepared. The author suggested that being apart from the decision-making process explained this insecurity. Article 7 also claimed that PTs felt outsiders (p.247) sometimes due to the powerful situation that CTs kept in the classroom in relation to technologies. Article 34 reported a lack of confidence of PTs that blocked their contribution with new ideas, so they imitated and kept traditional uses of technologies.

Regarding the relationship between personal variables of PTs and the technological implementation, research is focused on self-efficacy, motivation, expectations, and satisfaction. Definitely, self-efficacy and self-perception of digital competence are the most explored variables in the study of management of technologies in practicum contexts. As article 8 already claimed, self-efficacy perception in using technology influences the integration of technologies at the schools. Article 18 also found a specific correlation: the higher perceived self-efficacy, the higher frequency of use of technologies. The opposite process is addressed since a strong self-perception of digital competence arose, but a poor performance was found too $(2 ; 16)$.

According to the Taylor's (2004) proposal, a great number of PTs are located in level 1 of the technological development model. It means that the level of digital competence is low, and a lack of reflection is a consequence of poor interactions with technologies. However, article 6 showed that PTs could effectively use ICT and their pedagogical competencies were increased. Article 30 also found a significant relationship between the university training and self-efficacy perception toward technological integration. In this line, article 21 reported a high digital competence self-perception due to field experiences. In contrast, article 23 found that the competency self-perception was high both initially and after teaching practices. Results show that the specifications of placement contexts play a relevant role to determine relationship between selfperception and real digital competence.

The second widely studied variables are attitudes and motivation toward technologies integration. Articles report positive attitudes and high motivation at the schools $(3 ; 6 ; 15 ; 17)$. In relation to expectations, article 24 found that PTs expected to have more learning technological opportunities, however, they found a lack of mastery experiences at the schools. Finally, article 35 concluded that the motivation is a strong factor to promote the use of technologies, and article 36 found that the integration of innovative technologies is influenced negatively if PTs show negative attitudes toward these resources.

The last highlighted personal variable was the model TPACK. The main conclusion from the review is that PTs showed a low TPACK when they managed technologies. Article 27 explained this tendency since PTs did not usually use technology to address learner's content understanding. Article 12 claimed that technologies were seen by PTs as tools to benefit their security and to follow their mentors' performance. Thus, we cannot talk about meaningful experiences in terms of TPACK. On the one hand, an improvement in different areas of the TPACK model is due to contextual factors such as expectations toward the CTs' performance. Article 10 pointed out practical situations, such as practicum, as useful spaces to understand the TPACK model. These authors reported that pedagogical knowledge presents a relationship with the strategies used by PTs. Article 14 also pointed out the length of placements and the perceived level of autonomy as determinant factors of the TPACK. Other authors (articles $24 ; 26 ; 29$ ) pointed out high expectations of PTs toward their improvement in TPACK through field experiences. However, they found a lack of scaffolding from their CTs. Related to the pedagogical issue, article 34 talked about the movement of PTs from their position as students toward the teachers' role to enhance pupils' learning. It means to leave their own learning in a second level. On the other hand, regarding the content and knowledge areas, article 35 also claimed that PTs show certain comfort 
when they use technological resources because they use them regularly; however, this familiarity does not imply a high mastery of pedagogical knowledge, nor reflection in the use (28).

\section{DISCUSSION AND CONCLUSIONS}

The present research studied the treatment of technologies made by the initial teacher education as well as by the schools in the practicum experiences of preservice teachers. To this end, a bibliometric and a thematic analysis were conducted.

From the bibliometric perspective, the conclusions point out to a lack of countries that investigate these topics jointly. Findings show that the number of publications related to the three cornerstones of the review (technologies, practicum and PTs in early childhood and primary education) is reduced. In the sample of journals, the highest publication rate is found in the years 2011 and 2017. The most used methodological design is qualitative through case studies. Most of the qualitative articles were found in Scopus and ERIC databases. The visual-bibliometric analysis conducted for WoS and Scopus databases was a demonstration to understand what terms and topics are presented in the searching related to the issue. From the homogeneity and density maps in WoS, three thematic clusters highlighted the PTs' training, the role of USs, and factors that intervene in the management of technologies. From the homogeneity and density maps in Scopus, four clusters were found focused on the ITE, the management of technologies made in the ITE and during practicum, and personal variables of PTs in these environments (i.e. TPACK).

From the thematic perspective, the findings show that technologies are studied as part of the ITE related to practicum experiences during the last decade. Three lines of research were found: the technological preparation at the University through the USs, the technological implementation in the practicum through the CTs, and the PT's personal variables that intervene in the management of technologies during field experiences.

Regarding the articles that examined the training provided by the ITE and the USs, it is concluded that the experiences at the university were focused on teaching PTs how to use applications and tools. These experiences are method courses and specific courses. Thus, although the intention was to scaffold the PTs beyond the feedback and encouragement of USs, the results showed that most PTs were not autonomous in their field experiences. They found a lack of guidance to implement these tools effectively; in fact, PTs reported that a follow up from their USs in these terms was considerably reduced. Since the ITE is mostly focused on teaching resources and tools, literature considers the strengthen of method courses, courses and preparatory courses focused on pedagogical possibilities of technologies (Haydn, 2014; Mabunda, 2013; Tondeur et al., 2019). Thus, little is still known about how universities address pedagogical strategies that technologies provide to confront curriculum issues as well as the personalization of the education.

Regarding the studies related to practicum settings, it is reported that PTs present limited knowledge when they go to the schools. Although they are well skilful with resources that may be used daily, there is a lack of pedagogical knowledge to apply them. In contrast, studies present that CTs showed better pedagogical knowledge, but they could not relate it with technologies. It could be categorised as a poorly compensated imbalance. McGarr and Ó Gallchóir (2020) insist on the relationship between university and schools to influence PTs's technology implementation. Thus, longitudinal studies that consider both US's and CT's roles are necessary to adjust this training. Specifically, strengthening the CTs' management of technologies is addressed as a concern for PTs. For instance, technology has been the only way to teach and learn through the first year of COVID-19 (Kim, 2020), therefore, it is important to understand how unpredictable situations may influence and condition not only children's learning, but also PT's learning. Different studies already claim that technology would be in the schools and teachers should be prepared (Byrnes et al., 2014; Chai \& Lim, 2011; Chigona, 2015; Roig-Vila et al., 2015). Due to this fact, technology and social media seem to be alternatives to train future teachers in classroom scenarios.

To conclude the thematic analysis, the revised manuscripts focused on personal variables of PTs reported high self-efficacy perceptions in contrast with a low digital competence at the schools. These results also 
pointed out low changes of PTs' TPACK after practicum due to disappointing school environments. Relevant contributions (Baydas \& Goktas, 2016; Maderick et al., 2015) explain that CT's role and internal variables are inseparable research topics. Moreover, the PTs' overview about education influenced their pedagogical responsibilities toward technologies and would determine the TPACK development. Thus, findings in this area encourage to investigate personal variables and the influence of US and CT roles.

Finally, due to the lack of depth and reflective practices through practicum, the Taylor's framework (2004) is proposed to understand the origin of generalisations in the thinking and understanding of PTs' uses of technology. In this line, Bahcivan et al. (2019) talked about a desirable step from simplistic and basic arguments when PTs start their field experiences, toward deeper and specific reasoning when they finish this period. Therefore, increasing the research into the field of technologies, ITE and practicum settings is recommended to improve the ITE and the subsequent professional performance at the schools. Considering the bibliometric and thematic conclusions, Figure 8 and Figure 9 summarize all this information visually.

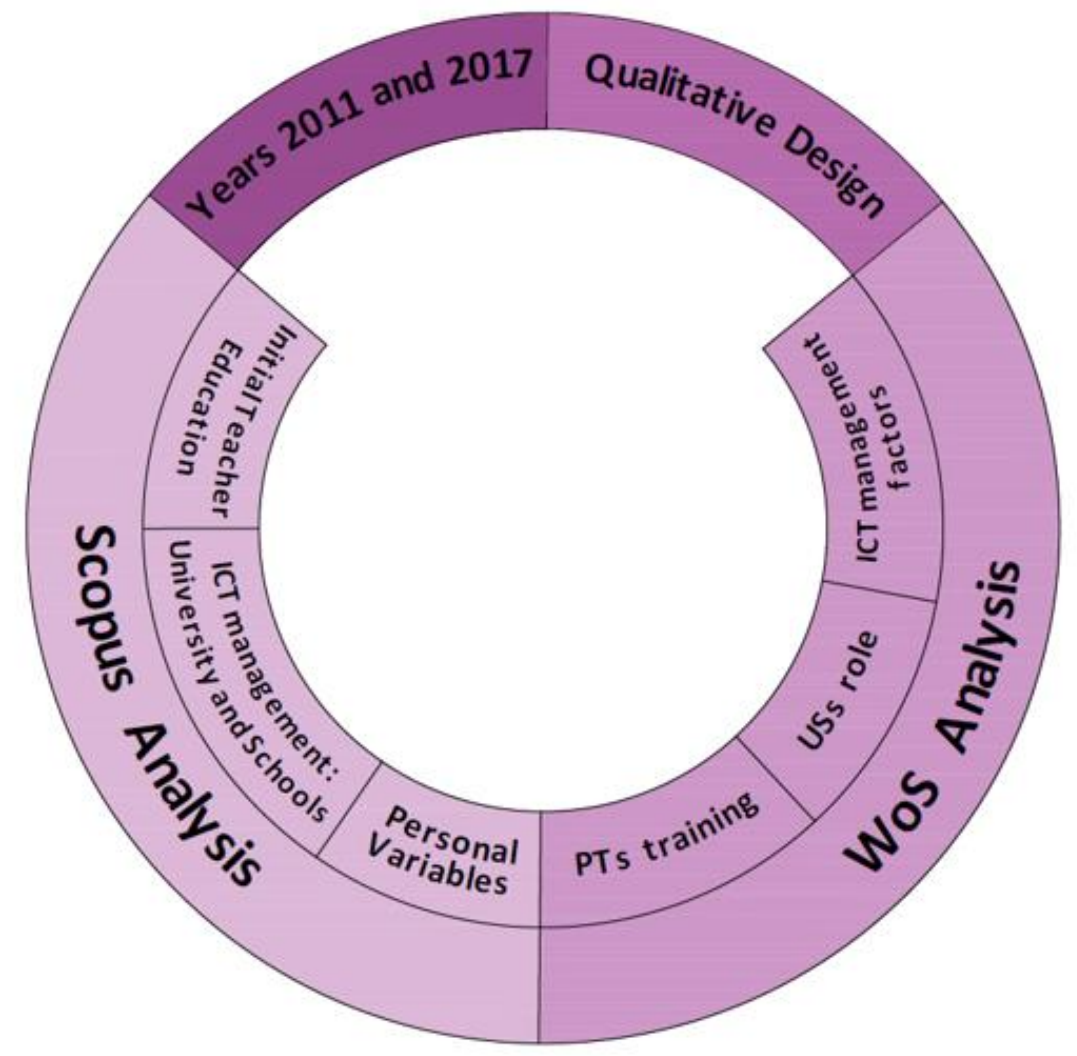

Figure 8. Diagram to summarize the conclusions from the bibliometric analysis 


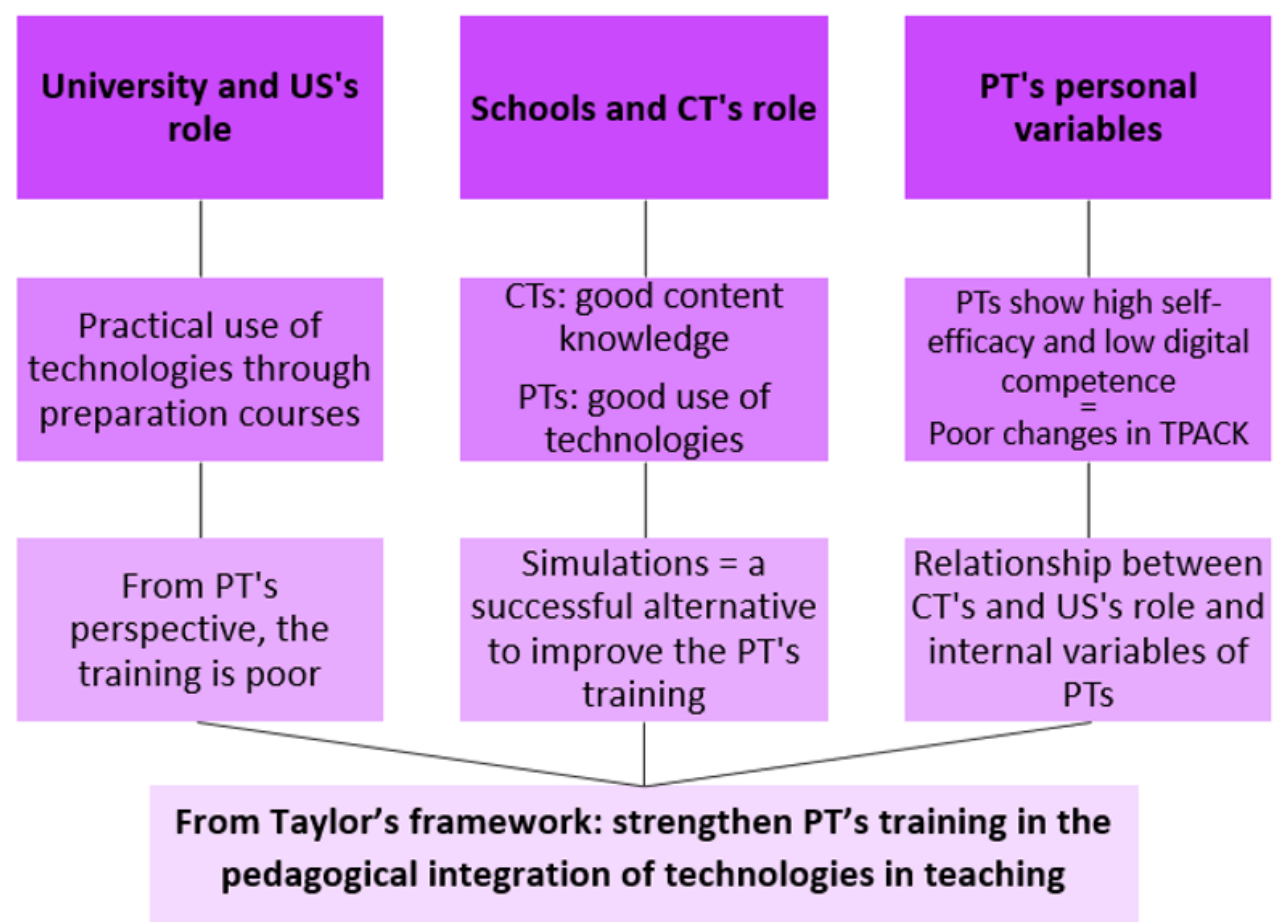

Figure 9. Diagram to summarize the conclusions from the thematic analysis

\section{LIMITATIONS}

This study presents some limitations. On the one hand, the bibliometric analysis could explore other educational platforms to deepen the terms more used in the searches related to the three cornerstones of the review. On the other hand, it is encouraged to examine the tensions between PT's goal of learning to use technologies in the practicum and the CT's goal of improving pupils learning. Therefore, this review proposes to inquire how to develop the PT's TPACK when CTs use traditional methods in the schools.

Author contributions: All authors were involved in concept, design, collection of data, interpretation, writing, and critically revising the article. All authors approve final version of the article.

Funding: The authors received no financial support for the research and/or authorship of this article.

Declaration of interest: Authors declare no competing interest.

Data availability: Data generated or analysed during this study are available from the authors on request.

\section{REFERENCES}

Area-Moreira, M., Hernández-Rivero, V., \& Sosa-Alonso, J. (2016). Modelos de integración didáctica de las TIC en el aula [Models of didactic integration of ICT in the classroom]. Comunicar: Revista Cientifica Iberoamericana de Comunicación y Educación [Communicate: Ibero-American Scientific Journal of Communication and Education], 47, 79-87. https://doi.org/10.3916/C47-2016-08

Aslan, A., \& Zhu, C. (2015). Pre-service teachers' perceptions of ICT integration in teacher education in Turkey. Turkish Online Journal of Educational Technology, 2015(3), 462-466. https://doi.org/10.1111/bjet. 12437

Aslan, A., \& Zhu, C. (2016). Influencing factors and integration of ICT into teaching practices of pre-service and starting teachers. International Journal of Research in Education and Science, 2(2), 359-370. https://doi.org/10.21890/ijres.81048

Aslan, A., \& Zhu, C. (2017). Investigating variables predicting Turkish pre-service teachers' integration of ICT into teaching practices. British Journal of Educational Technology, 48(2), 552-570. https://doi.org/10.1111/bjet.12437 
Bahcivan, E., Gurer, M. D., Yavuzalp, N., \& Akayoglu, S. (2019). Investigating the relations among pre-service teachers' teaching/learning beliefs and educational technology integration competencies: A structural equation modeling study. Journal of Science Education and Technology, 28(5), 579-588. https://doi.org/10.1007/s10956-019-09788-6

Baydas, O., \& Goktas, Y. (2016). Influential factors on preservice teachers' intentions to use ICT in future lessons. Computers in Human Behavior, 56, 170-178. https://doi.org/10.1016/j.chb.2015.11.030

Bladergroen, M. C., \& Chigona, W. (2019). Managing information and communication technology in South African classrooms: Pre-service teachers' experiences. Africa Education Review, 16(3), 22-35. https://doi.org/10.1080/18146627.2016.1224589

Browne, T. (2015). A case study of student teachers' learning and perceptions when using tablet applications teaching physical education. Asia-Pacific Journal of Health, Sport and Physical Education, 6(1), 3-22. https://doi.org/10.1080/18377122.2014.997858

Byrnes, M., Manente, C. J., Carolan, R. G., Hughes, M. C., Pickard, A., \& Kaufman, K. (2014). Information communication technology: Challenges \& some prospects from pre-service education to the classroom. Mid-Atlantic Education Review, 2(1), 1-11.

Cabero-Almenara, J., \& Martínez, A. (2019). Las tecnologías de la información y comunicación y la formación inicial de los docentes. Modelos y competencias digitales [Information and communication technologies and initial teacher training. Models and digital skills]. Profesorado. Revista de Currículum y Formación de Profesorado [Faculty. Journal of Curriculum and Teacher Training], 23(3), 247-268. https://doi.org/10.30827/profesorado.v23i3.9421

Caena F., \& Redecker, C. (2019). Aligning teacher competence frameworks to 21st century challenges: The case for the European digital competence framework for educators (DIGCOMPEDU). European Journal of Educaction, 54, 356-369. https://doi.org/10.1111/ejed.12345

Cakir, R., \& Yildirim, S. (2013). Who are the really? A review of the characteristics of pre-service ICT teachers in Turkey. Asia-Pacific Education Researcher, 24(1), 67-80. https://doi.org/10.1007/s40299-013-01599

Chai, C., \& Lim, C. (2011). The Internet and teacher eduation: Traversing between the digitized world and schools. Internet and Higher Education, 14(1), 1-9. https://doi.org/10.1016/j.iheduc.2010.04.003

Charbonneau-Gowdy, P. (2015). It takes a community to develop a teacher: Testing a new teacher education model for promoting ICT in classroom teaching practices in Chile. The Electronic Journal of E-Learning, 13(4), 237-249.

Chen, R. J. (2010). Investigating models for preservice teachers' use of technology to support studentcentered learning. Computers and Education, 55(1), 32-42. https://doi.org/10.1016/j.compedu.2009. 11.015

Chigona, A. (2015). Pedagogical shift in the twenty-first century: Preparing teachers to teach with new technologies. Africa Education Review, 12(3), 478-492. https://doi.org/10.1080/18146627.2015. 1110912

Dong, C., \& Mertala, P. (2019). It is a tool, but not a 'must': Early childhood preservice teachers' perceptions of ICT and its affordances. Early Years, 0O(00), 1-16. https://doi.org/10.1080/09575146.2019.1627293

Fernández-Batanero, J. M., Reyes-Rebollo, M. M., \& Montenegro-Rueda, M. (2019). Impact of ICT on students with high abilities. Bibliographic review (2008-2018). Computers and Education, 137, 48-58. https://doi.org/10.1016/j.compedu.2019.04.007

Figg, C., \& Jamani, K. J. (2011). Exploring teacher knowledge and actions supporting technology-enhanced teaching in elementary schools: Two approaches by pre-service teachers. Australasian Journal of Educational Technology, 27(7), 1227-1246. https://doi.org/10.14742/ajet.914 
Franklin, R., Mitchell, J., Walters, K. S., Livingston, B., Lineberger, M. B., Putman, C., Yarborough, R., \& KargesBone, L. (2018). Using swivl robotic technology in teacher education preparation: A pilot study. TechTrends, 62(2), 184-189. https://doi.org/10.1007/s11528-017-0246-5

Gao, P., Chee, T. S., Wang, L., Wong, A., \& Choy, D. (2011). Self-reflection and preservice teachers' technological pedagogical knowledge: Promoting earlier adoption of student-centred pedagogies. Australasian Journal of Educational Technology, 27(6), 997-1013. https://doi.org/10.14742/ajet.925

Gill, L., \& Dalgarno, B. (2017). A qualitative analysis of pre-service primary school teachers' TPACK development over the four years of their teacher preparation programme. Technology, Pedagogy and Education, 26(4), 439-456. https://doi.org/10.1080/1475939X.2017.1287124

Gill, L., Dalgarno, B., \& Carlson, L. (2014). How does pre-service teacher preparedness to use ICTs for learning and teaching develop through their degree program? Australian Journal of Teacher Education, 40(1), 36-60. https://doi.org/10.14221/ajte.2015v40n1.3

Goldstein, O., \& Tesler, B. (2017). The impact of the national program to integrate ICT in teaching in preservice teacher training. Interdisciplinary Journal of E-Skills and Lifelong Learning, 13, 151-166. https://doi.org/https://doi.org/10.28945/3876

Guillén-Gámez, F. D., Mayorga-Fernández, M. J, \& Álvarez-García, F. J. (2018). A study on the actual use of digital competence in the practicum of education degree. Technology, Knowledge and Learning, 0123456789. https://doi.org/10.1007/s10758-018-9390-z

Habibi, A., Razak, R. A., Yusop, F. D., Mukminin, A., \& Yaqin, L. N. (2020). Factors affecting ICT integration during teaching practices: A multiple case study of three Indonesian universities. Qualitative Report, 25(5), 1127-1144. https://doi.org/10.46743/2160-3715/2020.4150

Hammond, M., Reynolds, L., \& Ingram, J. (2011). How and why do student teachers use ICT? Journal of Computer Assisted Learning, 27(3), 191-203. https://doi.org/10.1111/j.1365-2729.2010.00389.x

Han, I., Shin, W. S., \& Ko, Y. (2017). The effect of student teaching experience and teacher beliefs on preservice teachers' self-efficacy and intention to use technology in teaching. Teachers and Teaching: Theory and Practice, 23(7), 829-842. https://doi.org/10.1080/13540602.2017.1322057

Haydn, T. (2014). How do you get pre-service teachers to become 'good at ICT' in their subject teaching? The views of expert practitioners. Technology, Pedagogy and Education, 23(4), 455-469. https://doi.org/10.1080/1475939X.2014.892898

$\mathrm{Hu}, \mathrm{X} .$, \& Yelland, N. (2017). An investigation of preservice early childhood teachers' adoption of ICT in a teaching practicum context in Hong Kong. Journal of Early Childhood Teacher Education, 38(3), 259274. https://doi.org/10.1080/10901027.2017.1335664

Instefjord, E. J., \& Munthe, E. (2017). Educating digitally competent teachers: A study of integration of professional digital competence in teacher education. Teaching and Teacher Education, 67, 37-45. https://doi.org/10.1016/j.tate.2017.05.016

Jita, T. (2016). Pre-service teachers' competence to teach science through information and communication technologies in South Africa. Perspectives in Education, 34(3), 15-28. https://doi.org/10.18820/ 2519593X/pie.v34i3.2

Kim, J. (2020). Learning and teaching online during COVID-19: Experiences of student teachers in an early childhood education practicum. International Journal of Early Childhood, 0123456789, 1-14. https://doi.org/10.1007/s13158-020-00272-6

LaBoskey, V.K. (1994). Development of reflective practice: A study of preservice teachers. Teachers College Press.

Levine-Clark, M., \& Gil, E. (2009). A comparative analysis of social sciences citation tools. Online Information Review, 33(5), 986-996. https://doi.org/10.1108/14684520911001954 
Mabunda, P. L. (2013). Towards a theoretical framework for the use of ICT strategies for teaching practicum supervision. Africa Education Review, 10(sup1), 7-27. https://doi.org/10.1080/18146627.2013.855411

Maderick, J. A., Zhang, S., Hartley, K., \& Marchand, G. (2015). Preservice teachers and self-assessing digital competence. Journal of Educational Computing Research, 54(3), 326-351. https://doi.org/10.1177/ 0735633115620432

Maestre, M. M., Nail, O., \& Rodríguez-Hidalgo, A. J. (2017). Desarrollo de competencias tic y para la educación inclusiva en la formación inicial práctica del profesorado [Development of ict skills and for inclusive education in the initial practical training of teachers]. Bordón. Revista de Pedagogía [Staff. Pedagogy Magazine], 69(3), 57-72. https://doi.org/10.13042/Bordon.2017

Martinovic, D., \& Zhang, Z. (2012). Situating ICT in the teacher education program: Overcoming challenges, fulfilling expectations. Teaching and Teacher Education, 28(3), 461-469. https://doi.org/10.1016/ j.tate.2011.12.001

McGarr, O., \& Ó Gallchóir, C. (2020). Exploring pre-service teachers' justifications for one-to-one technology use in schools: Implications for initial teacher education. Technology, Pedagogy and Education, 29(4), 1-14. https://doi.org/10.1080/1475939X.2020.1784261

Melville, W., Bowen, G. M., \& Passmore, G. (2011). Pre-service teacher reflections, video-conference and WebCT: An exploratory case study. Electronic Journal of Research in Educational Psychology, 9(2), 799822. https://doi.org/10.25115/ejrep.v9i24.1474

Merc, A. (2015). Using technology in the classroom: A study with Turkish pre-service EFL teachers. Turkish Online Journal of Educational Technology, 14(2), 229-240.

Mishra, P., \& Koehler, M. J. (2006). Technological pedagogical content knowledge: A framework for teacher knowledge. Teachers College Record, 108(6), 1017-1054. https://doi.org/10.1111/j.1467-9620.2006. 00684.x

Mouza, C., Karchmer-Klein, R., Nandakumar, R., Yilmaz Ozden, S., \& Hu, L. (2014). Investigating the impact of an integrated approach to the development of preservice teachers' technological pedagogical content knowledge (TPACK). Computers and Education, 71, 206-221. https://doi.org/10.1016/j.compedu.2013. 09.020

Ntuli, E. (2017). Evaluation of Instructional technology: A case study of early childhood teacher candidates. Open Journal for Educational Research, 1(1), 1-14. https://doi.org/10.32591/coas.ojer.0101.01001n

Olivares, D. D., \& Castillo, R. R. (2018). ICT in the classroom: Primary education student teachers' perceptions of the interactive whiteboard during the teaching practicum. Education and Information Technologies, 23(6), 2309-2321. https://doi.org/10.1007/s10639-018-9716-4

Polly, D., Mims, C., Shepherd, C. E. \& Inan, F. (2010). Evidence of impact: Transforming teacher education with preparing tomorrow's teachers to teach with technology (PT3) grants. Teaching and Teacher Education, 26, 863-870. https://doi.org/10.1016/j.tate.2009.10.024

Pranckutè, R. (2021). Web of Science (WoS) and Scopus: The titans of bibliographic information in today's academic world. Publications, 9(1), 12. https://doi.org/10.3390/publications9010012

Reisoglu, I., \& Cebi, A. (2020). How can the digital competences of pre-service teachers be developed? Examining a case study through the lens of DigComp and DigCompEdu. Computers and Education, 156, 103940. https://doi.org/10.1016/j.compedu.2020.103940

Roig-Vila, R., Mengual-Andrés, P., \& Quinto-Medrano, P. (2015). Conocimientos tecnológicos, pedagógicos y disciplinares del profesorado de Primaria [Technological, pedagogical and disciplinary knowledge of Primary school teachers]. Comunicar, 23(45), 151-159. https://doi.org/10.3916/C45-2015-16

Rowston, K., Bower, M., \& Woodcock, S. (2020). The lived experiences of career-change pre-service teachers and the promise of meaningful technology pedagogy beliefs and practice. Education and Information Technologies, 25(2), 681-705. https://doi.org/10.1007/s10639-019-10064-8 
Sahin, O., \& Kabakci, I. (2014). Investigation of prospective teachers' information and communication technology integration practices in terms of transformative learning theory. Educational Sciences: Theory \& Practice, 14(6), 2293-2303. https://doi.org/10.12738/estp.2014.6.2076

Sasaki, R., Goff, W., Dowsett, A., Parossien, D., Matthies, J., Di lorio, C., Montey, S., Rowe, S., \& Puddy, G. (2020). The practicum experience during COVID-19 -- Supporting initial teacher education student's practicum experience through a simulated classroom. Journal of Technology and Teacher Education, 28(2), 329-339.

Schön, D. (1987). Educating the reflective practitioner: Towards a new design for teaching and learning in the professions. Jossey-Bass.

Sola-Martínez, T., Cáceres-Reche, M. P., Romero-Rodríguez, J. J. \& Ramos-Navas-Parejo, M. (2020). Estudio bibliométrico de los documentos indexados en Scopus sobre la formación del profesorado en TIC que se relacionan con la calidad educativa [Bibliometric study of documents indexed in Scopus on ICT teacher training that are related to educational quality]. Revista Electrónica Interuniversitaria de Formación del Profesorado [Interuniversity Electronic Journal of Teacher Training], 23(2), 19-35. https://doi.org/10.6018/reifop.418611

Starkey, L. (2020). A review of research exploring teacher preparation for the digital age. Cambridge Journal of Education, 50(1), 37-56. https://doi.org/10.1080/0305764X.2019.1625867

Szeto, E., \& Cheng, A. Y. N. (2014). Exploring the usage of ICT and YouTube for teaching: A study of pre-service teachers in Hong Kong. Asia-Pacific Education Researcher, 23(1), 53-59. https://doi.org/10.1007/s40299-013-0084-y

Szeto, E., \& Cheng, A. Y. N. (2016). Pedagogies across subjects: What are preservice teachers' TPACK patterns of integrating technology in practice? Journal of Educational Computing Research, 55(3), 346-373. https://doi.org/10.1177/0735633116667370

Tondeur J., Aesaert K., Prestridge S., \& Consuegra E. (2018). A multilevel analysis of what matters in the training of pre-service teacher's ICT competencies. Computers \& Education, 122, 32-42. https://doi.org/10.1016/j.compedu.2018.03.002

United Nations Educational, Scientific and Cultural Organization [UNESCO]. (2016). Tecnologías digitales al servicio de la calidad educative [Digital technologies at the service of educational quality]. UNESCO.

Vratulis, V., Clarke, T., Hoban, G., \& Erickson, G. (2011). Additive and disruptive pedagogies: The use of slowmotion as an example of digital technology implementation. Teaching and Teacher Education, 27(8), 1179-1188. https://doi.org/10.1016/j.tate.2011.06.004

Vygotsky, L. S. (1978). Mind in society. Harvard University Press.

Wake, D. G. (2013). Teacher candidates' perceptions of technology used to support literacy practices. Technological Tools for the Literacy Classroom, 13, 220-242. https://doi.org/10.4018/978-1-46663974-4.ch013

Walker, Z., Kho, H. H., Tan, D., \& Lim, N. (2020). Practicum teachers' use of mobile technology as measured by the technology acceptance model. Asia Pacific Journal of Education, 40(2), 230-246. https://doi.org/10.1080/02188791.2019.1671808

Zipke, M. (2017). Preparing teachers to teach with technology: Examining the effectiveness of a course in educational technology. The New Educator, 14(4), 342-262. https://doi.org/10.1080/1547688X.2017. 1401191

Correspondence: Irene García-Lázaro, Department of Communication and Education, Faculty of Social and Human Sciences, Universidad Loyola Andalucía, Seville, Spain and Department of Research Methods and Diagnosis in Education, Faculty of Education Sciences, University of Seville, Seville, Spain.

E-mail: igarcia@uloyola.es 